\title{
ASSESSMENT OF SOIL LOSS SUSCEPTIBILITY IN SANTA RITA WATERSHED IN SOUTHERN BRAZIL
}

\author{
Mayara Zanchin ${ }^{1}$, Maíra M. de Moura ${ }^{*}$, Maria C. M. Nunes ${ }^{1}$, \\ Ivana K. Tuchtenhagen ${ }^{1}$, Cláudia L. R. de Lima ${ }^{1}$
}

$1^{*}$ Corresponding author. Federal University of Pelotas/ Pelotas - RS, Brazil.

E-mail: martimdemoura@gmail.com | ORCID ID: https://orcid.org/0000-0001-6618-2327

\section{KEYWORDS}

RUSLE, soil loss index, soil loss tolerance, water erosion

\begin{abstract}
Estimation of soil loss susceptibility is of great importance for the management of watersheds. Thus, several models for soil loss prediction have been proposed. This study estimated the total annual soil loss for the Santa Rita watershed, located in southern Brazil, using the Revised Universal Soil Loss Equation. In addition, a classification to soil loss index $\left(\mathrm{I}_{\mathrm{SL}}\right)$ was proposed to identify regions with critical soil loss values. Altitude, slope, land use, and soil class data were applied to the model, in addition to spatial information for 78 soil samples collected within the study area. It was found that there is an average annual loss of $35.94 \mathrm{Mg} \mathrm{ha}^{-1}$ year $^{-1}$, with the most substantial loss occurring in areas with predominantly exposed soil and annual cropping. Furthermore, the ISL values indicated that approximately $50 \%$ of the study area is experiencing erosion estimates above the tolerable limit. Results emphasize the need for changes in conservation and application practices present in the watershed, considering land use and soil bearing capacity.
\end{abstract}

\section{INTRODUCTION}

The water and sediment delivery through water bodies towards the oceans is a natural consequence of the water cycle. With population growth and intensification of anthropogenic activities associated with changes and intensive use of soil, the water erosion process is accelerated and intensified (Napoli et al., 2016), promoting soil loss to occur above the tolerable limits established in the literature. An increase in soil loss is directly associated with the number of available nutrients, reducing agricultural productivity and causing eutrophication of water bodies (Bakker et al., 2007). Studies have reported that soil disaggregation interferes with basic soil properties relevant to the cultivation system, in addition to increasing production costs (Derpsch et al., 2014; Reicosky, 2015).

In tropical and subtropical regions, agricultural practices have intensified soil erosion, mainly because of the difficulty of implementing appropriate soil conservation measures (Beskow et al., 2009). Some research indicates that the use of conservationist measures depends on several factors, such as economic viability, lack of knowledge about new techniques, and social or cultural aspects (Wreford et al., 2017; Rocha et al., 2020). In this context, it is necessary to map soil loss susceptibility for the planning and management of watersheds (Markose \& Jayappa, 2016). However, there is still a shortage of data obtained in the field, which is timeconsuming and costly (Batista et al., 2017). Several mathematical models for estimating water erosion and sediment yield have been proposed, including the Soil and Water Assessment Tool (SWAT) (Arnold et al., 1998), Water Erosion Prediction Project (WEPP) (Flanagan \& Nearing, 1995), Erosion Productivity Impact Calculator (EPIC) (Sharpley \& Williams, 1990), Universal Soil Loss Equation (USLE) (Wishmeier \& Smith, 1978), and Revised Universal Soil Loss Equation (RUSLE) (Renard et al., 1997).

RUSLE is an erosion model designed to predict the long-term average annual soil loss (A) (Renard et al., 1997), which has been widely used, especially in places with limited or non-existent data (Steinmetz et al., 2018). Estimates were made based on climatic variables (factor $\mathrm{R}$ ), soil (factor K), topographic (factors L and S), and soil use, management, and conservation conditions (factors $\mathrm{C}$ and $\mathrm{P}$, respectively). According to Merritt et al. (2003), RUSLE was developed for small hillslopes; however, several studies have used it to estimate soil erosion at the watershed scale (Gianinetto et al., 2019; Gomes et al.,

${ }^{1}$ Federal University of Pelotas/ Pelotas - RS, Brazil

Area Editor: Teresa Cristina Tarlé Pissarra

Received in: 7-11-2020

Accepted in: 5-19-2021 
2019; Panditharathne et al., 2019; Lense et al., 2020). With the advent of Geographic Information Systems (GIS), it is possible to estimate soil loss pixel-by-pixel. However, this model does not provide sediment deposition and sediment delivery (Benavidez et al., 2018). Regarding watershed management, estimating soil erosion rates in subwatersheds with different characteristics is essential for soil and water conservation projects (Kavian et al., 2017).

The spatial variability of soil loss susceptibility at the watershed scale has helped several studies concerning the public water supply. In this context, some authors have studied other negative effects of water erosion, such as siltation of channels and reservoirs and compromised water quality (Valadão et al., 2018; Santos et al., 2020). The Santa Rita Watershed (SRW) is a subwatershed of the Fragata River Watershed (FRW), which is of great socioeconomic importance in the region and is responsible for part of the water supply in the city of Pelotas, RS (Valadão et al., 2018). Furthermore, SRW has a large agricultural area within its natural space, affecting water quality and modifying the landscape that encompasses its water resources. Therefore, the present study aimed to obtain the RUSLE parameters, total annual loss, and proposed a classification for the index soil loss, allowing the identification of the most susceptible soil loss places in the Santa Rita watershed, located in the Rio Grande do Sul Southern Brazil.

\section{MATERIAL AND METHODS}

\section{Study area and database}

The study area comprises the Santa Rita watershed (SRW), $9.10 \mathrm{~km}^{2}$, located in the city of Pelotas, south of Rio Grande do Sul (RS) (Figure 1). The SRW is a subwatershed of the FRW, which is strategic for economic and social development in the state of RS (Beskow et al., 2016). The region's climate is Cfa Köppen's type, humid subtropical, characterized by hot summers with temperatures above $22{ }^{\circ} \mathrm{C}$ and an annual average rainfall of 1,385.6 mm (Alvares et al., 2013).

SRW is a direct affluent of the Moreira Water Treatment Plant (Moreira WTP) (Figure 1). It consists of an untreated water accumulation dam and serves only to provide the treatment plant, passing the water through filters and completing conventional treatment. In addition, Moreira WTP supplies reservoirs responsible for delivering water to several neighborhoods in the city of Pelotas.

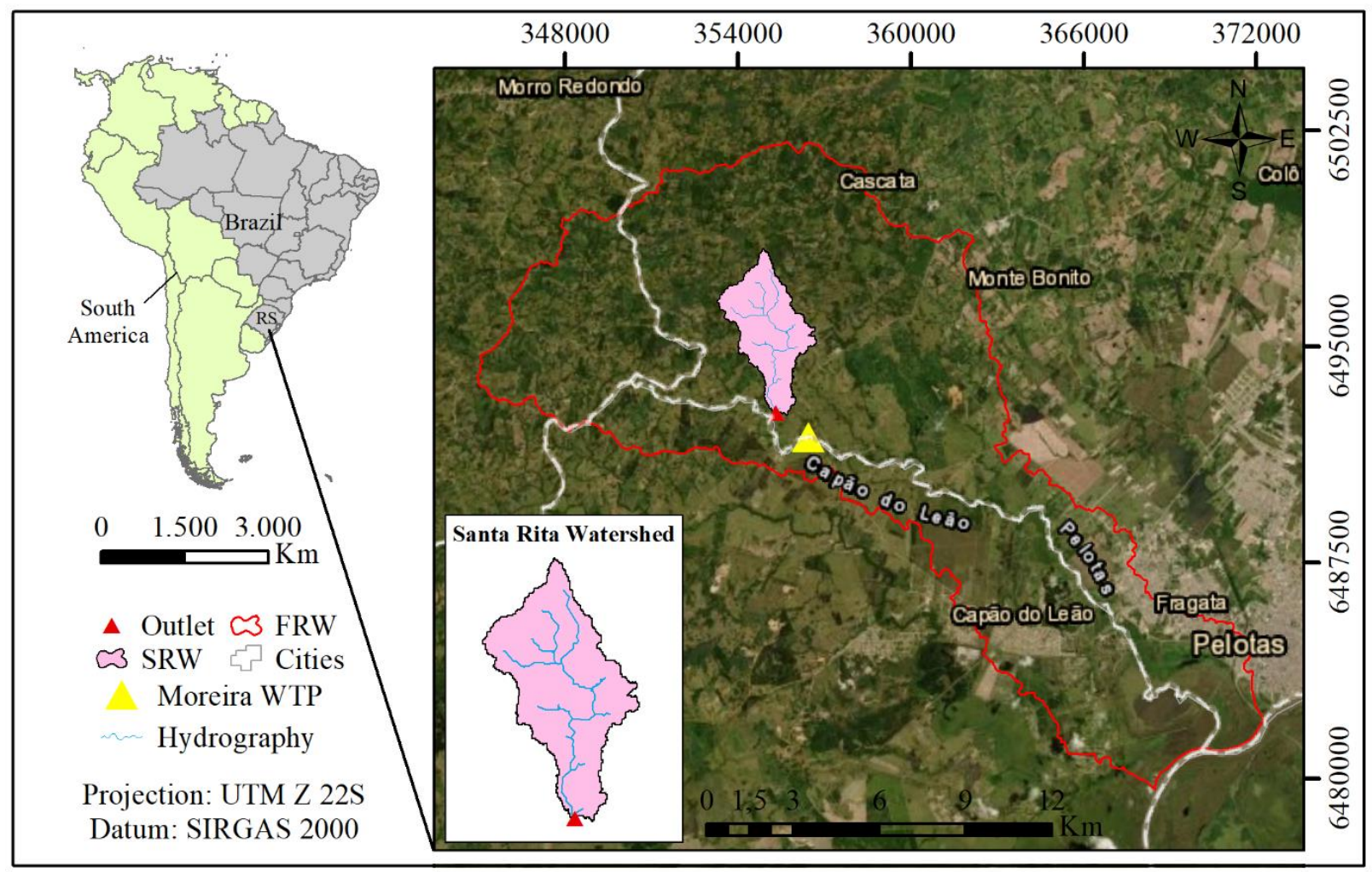

FIGURE 1. Location of the Fragata River Watershed (FRW) and the Santa Rita Watershed (SRW) in the state of Rio Grande do Sul (RS), Southern Brazil.

Fully inserted in the Pampa biome, the SRW is characteristic of the region, predominantly rupestrian vegetation, with areas destined for agriculture and grassland in the great majority (Lupatini et al., 2013). The soil classes of the SRW were obtained from mapping performed by Cunha et al. (2006). The soils present in the SRW are RedYellow Argisol (72.31\%), Yellow Argisol (25.52\%), and Haplic Planossol (2.17\%) (Figure 2a). In addition, data from the granulometric analyses performed on 78 soil samples distributed throughout the SRW (Table 1) was used.
Land use classes were obtained through supervised classification carried out in the software QGIS 3.4.3, using false-color composite 6-5-4. In addition, field-level investigations were conducted before classifications to observe the different uses and management in the watershed. A Landsat 8 image with a spatial resolution of 30 m taken on March 8, 2019 with point orbit 221082, made available by the United States Geological Survey (USGS), was used. As a result, the following classes of land use were identified: water bodies (0.77\%), annual cropping (14.11\%), 
grassland $(52.27 \%)$, exposed soil $(4.76 \%)$, and native forest $(29.09 \%)$ (Figure $2 b)$. In addition, a quarry area $(\sim$ $0.4 \mathrm{~km}^{2}$ ) was identified but disregarded in the analysis following the suggestions of Martín Duque et al. (2015).

Delimitation and characterization of the SRW were performed automatically using ArcGIS 10.1. software (ESRI, 2014). The digital elevation model (DEM) of the Shuttle Radar Topographic Mission (SRTM), made available by the USGS, was used. All products derived from the DEM were used with a spatial resolution of $30 \mathrm{~m}$.
SRW altitudes ranged from 42 to $228 \mathrm{~m}$, with an average altitude of $108 \mathrm{~m}$ (Figure 2c). Based on the slope classification proposed by EMBRAPA (1979), it is clear that the watershed has a predominantly undulated topography, with $38.98 \%$ and $47.42 \%$ of the area framed as smooth-undulated $(3 \%-8 \%)$ and undulated $(8 \%-$ $20 \%)$, respectively. The flat regions $(0 \%-3 \%)$ of the watershed corresponded to $11.42 \%$, whereas $2.18 \%$ of the area had a strongly undulated topography $(20 \%-45 \%)$ (Figure 2d).

TABLE 1. Minimum, average, and maximum values for the clay, silt, and sand fractions obtained in each soil class of the Santa Rita Watershed (SRW) located in Southern Brazil.

\begin{tabular}{|c|c|c|c|c|c|}
\hline \multirow{2}{*}{ Soil classes } & \multirow{2}{*}{-} & \multirow{2}{*}{$\%$ Clay } & \multirow{2}{*}{$\%$ Silt } & \multicolumn{2}{|c|}{$\%$ Sand } \\
\hline & & & & Total & Very thin \\
\hline \multirow{3}{*}{ Yellow Argisol (Acrisol $\left.{ }^{1}\right)$} & Minimum & 16.2 & 19.2 & 41.9 & 4.8 \\
\hline & Maximum & 32.6 & 30.4 & 54.5 & 6.2 \\
\hline & Average & 24.4 & 24.8 & 48.2 & 5.5 \\
\hline \multirow{3}{*}{ Red-Yellow Argisol (Acrisol ${ }^{1}$ ) } & Minimum & 16.6 & 13.2 & 27.9 & 3.1 \\
\hline & Maximum & 39.6 & 46.1 & 60.0 & 6.7 \\
\hline & Average & 28.1 & 29.6 & 43.9 & 4.9 \\
\hline \multirow{3}{*}{ Haplic Planosol (Planosol $\left.{ }^{1}\right)$} & Minimum & 16.2 & 18.1 & 52.9 & 5.9 \\
\hline & Maximum & 19.2 & 24.7 & 57.7 & 6.4 \\
\hline & Average & 17.7 & 21.4 & 55.3 & 6.1 \\
\hline
\end{tabular}




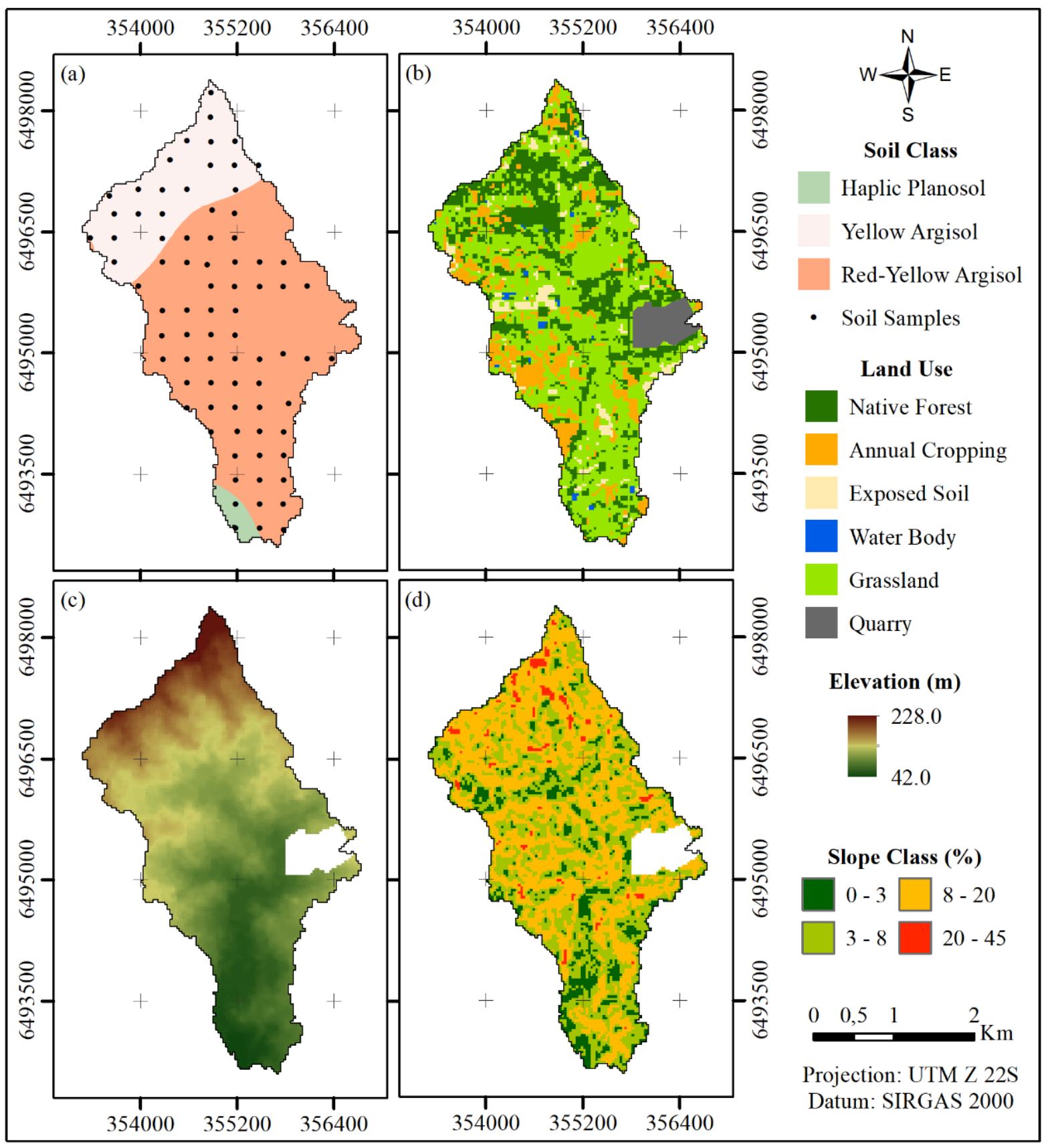

FIGURE 2. (a) Soil samples and soil classes, adapted from Cunha et al. (2006); (b) Land use maps; (c) digital elevation model; and (d) slope classes of the Santa Rita Watershed (SRW) located in Southern Brazil.

\section{The Revised Universal Soil Loss Equation}

The Revised Universal Soil Loss Equation (RUSLE) described by Renard et al. (1997) (Equation 1) was used to estimate soil loss. The RUSLE equation was performed with ArcGIS 10.1® software (ESRI, 2014), using the pixel as the unit of analysis, conserving the spatial resolution of the database $(30 \mathrm{~m})$.

$$
\mathrm{A}=\mathrm{R} \mathrm{K} \text { LS CP }
$$

Where:

$\mathrm{A}$ is the average annual soil loss per unit area $(\mathrm{Mg}$ ha $^{-1}$ year $^{-1}$ );

$\mathrm{R}$ is rainfall erosivity $\left(\mathrm{MJ} \mathrm{mm} \mathrm{ha}^{-1} \mathrm{~h}^{-1}\right.$ year $\left.^{-1}\right)$;

$\mathrm{K}$ is soil erodibility $\left(\mathrm{Mg} \mathrm{h} \mathrm{MJ}^{-1} \mathrm{~mm}^{-1}\right)$;
LS is the topographic factor (dimensionless), and

$\mathrm{CP}$ is the soil use, management, and conservation conditions (dimensionless).

\section{Rainfall erosivity (R)}

Due to the lack of data throughout the national territory, Mello et al. (2013) proposed R factor equations for Brazilian regions. These equations were obtained from multiple regressions with simplified and easily acquired parameters, such as altitude, latitude, and longitude. This study opted for using the equation proposed for the southern region of Brazil (Equation 2) to obtain the values of $R$.

$\mathrm{R}=2610770-60.44 \mathrm{Z}+98.839 \mathrm{LO}-1114.68 \mathrm{LA}^{2}+938.47 \mathrm{LO}^{2}$

$-1.185 \mathrm{LALO}+1.1885 \mathrm{LO}^{2} \mathrm{LA}^{2}+0.01494 \mathrm{LA}^{2} \mathrm{LO}^{3}$ 
Where:

$\mathrm{R}$ is the rainfall erosivity (MJ mm ha ${ }^{-1} \mathrm{~h}^{-1}$ year ${ }^{-1}$ );

$\mathrm{Z}$ is the altitude (m), LA is the latitude (decimal degrees), and

LO is the longitude (decimal degrees).

Subsequently, these values were classified according to Carvalho (2008): $\mathrm{R}<2,452$ : low; $2,452<\mathrm{R}<$ 4,905: medium; 4,905 < $\mathrm{R}<$ 7,357: medium-strong; 7,357 $<\mathrm{R}<9,810$ : strong and $\mathrm{R}>9,810$ : very strong.

\section{Soil erodibility (K)}

When data collected in the field are available, the Bouyoucos equation (Equation 3) has been used (Anache et al., 2015; Khan et al., 2019). Thus, for each soil sample collected in the SRW (Figure 2), the K value was obtained based on sand, silt, and clay fractions. Subsequently, these $\mathrm{K}$ values were spatialized for the watershed using ordinary kriging, using the automap tool (Hiemstra et al., 2009), of the statistical software R.

$$
\mathrm{K}=\frac{(\% \text { sand }+\% \text { silt })}{\% \text { clay }} 0.01
$$

Where:

$\mathrm{K}$ is soil erodibility $\left(\mathrm{Mg} \mathrm{h} \mathrm{MJ}^{-1} \mathrm{~mm}^{-1}\right)$, and

$\%$ sand, \% silt, and \% clay represent the percentages of the sand, silt, and clay fractions, respectively, in the soil sample.

Typical erodibility values for the watershed soils were obtained from the literature. All values were obtained from field experiments conducted on soils in Rio Grande do Sul. The values used for erodibility factors were as follows: Yellow Argisol, 0.0300 (Denardin, 1990); RedYellow Argisol, 0.0338 (Silva, 2016); and Haplic Planosol, 0.0553 (Miguel, 2010).

\section{Topographic factor (LS)}

Among the numerous proposals for calculating the LS factor available in the literature, the methodology proposed by Moore \& Burch (1986) (Equation 4) stands out. The authors proposed determining the LS factor by incorporating the unit potential energy, assuming that the water on the soil surface has energy capable of breaking down and transporting particles in the direction of the slope. In this way, it is possible to spatially represent the LS factor in areas of complex slopes, such as watersheds (Minella et al., 2010).

$$
\mathrm{LS}=\left[\left(\frac{\mathrm{FA} \mathrm{b} \mathrm{b}}{22.13}\right)^{0.40}\left(\frac{\operatorname{sen}(\beta)}{0.0896}\right)^{1.3}\right]
$$

Where:

FA is the accumulated flow (cell);

$\mathrm{b}$ is the spatial resolution of the cell (m);

$\beta$ is the slope (degrees), and

$i$ is a cell in the watershed matrix file.

\section{Cover management and support practice factors (CP)}

Values were obtained from the literature for the use and management of this study. All values were obtained from field experiments carried out on soils in São Paulo (grassland and annual cropping, soybean) and Rio Grande do Sul States (native forest), and RUSLE guide (water body and exposed soil). The values used for the cover factor were as follows: annual cropping, 0.2116 (Silva \& Luchiari, 2016); water body, 0.00 (Wischmeier \& Smith, 1978); exposed soil, 1.00 (Wischmeier \& Smith, 1978); Grassland, 0.0500 (Silva et al., 2010); and native forest, 0.0150 (Silva et al., 2016). For the P factor, the value of 1.0 was used since no conservationist erosion control practices were identified, following the recommendations of Beskow et al. (2009) and Batista et al. (2017).

\section{Tolerance of soil losses}

The tolerance of soil loss (Table 2) was obtained using the methodology of Smith \& Stamey (1964) (Equation 5).

$$
\mathrm{T}=10(h D s f)
$$

Where:

$\mathrm{T}$ is soil loss tolerance $\left(\mathrm{Mg} \mathrm{ha}^{-1}\right.$ year $\left.^{-1}\right)$;

$\mathrm{h}$ is the effective soil depth limited to $1000 \mathrm{~mm}$ of each soil (mm);

$\mathrm{f}$ is a conversion factor related to the textural gradient, and

Ds is the soil density value $\left(\mathrm{Mg} \mathrm{m}^{-3}\right)$.

\begin{tabular}{|c|c|c|c|c|}
\hline Soil & $\mathrm{f}$ & $\mathrm{h}(\mathrm{m})$ & $\begin{array}{c}\text { Ds } \\
\left(\mathrm{Mg} \mathrm{m}^{-3}\right)\end{array}$ & $\begin{array}{c}\text { Tolerance } \\
\left(\mathrm{Mg} \mathrm{ha}^{-1} \text { year }^{-1}\right)\end{array}$ \\
\hline Yellow Argisol & 0.4 & 1.00 & 1.52 & 6.06 \\
\hline $\begin{array}{l}\text { Red-Yellow } \\
\text { Argisol }\end{array}$ & 0.6 & 1.00 & 1.52 & 9.10 \\
\hline Haplic Planosol & 1.0 & 0.72 & 1.66 & 11.99 \\
\hline
\end{tabular}

TABLE 2. Tolerance of soil loss values for soils of Santa Rita Watershed (SRW), located in Southern Brazil.

The effective soil depth (h) and density (Ds) were affected by the average values of the soil samples for each class. The conversion factor $f$ converts the previously obtained soil loss tolerance into permanent soil loss. It was determined based on the textual gradient of the soil profiles, following the values proposed by Mannigel et al. (2002).

\section{Classification index of soil loss}

The index of soil loss ( $\left.\mathrm{I}_{\mathrm{sL}}\right)$ allows the identification of regions in critical situations of soil loss (Ghafari et al., 2017; Sudhishri et al., 2014) and aims to create strategies for soil management and conservation. The $\mathrm{I}_{\mathrm{SL}}$ was calculated using [eq. (6)] and was classified as follows: $\mathrm{I}_{\mathrm{SL}}$ $<1$, very low; $1<\mathrm{I}_{\mathrm{SL}}<2$, low; $2<\mathrm{I}_{\mathrm{SL}}<4$, medium; $4<$ $\mathrm{I}_{\mathrm{SL}}<6$, high; and $\mathrm{I}_{\mathrm{SL}}>6$, very high.

$$
\mathrm{I}_{\mathrm{SL}}=\frac{\mathrm{A}}{\mathrm{T}}
$$


Where:

A is the soil loss measured by RUSLE (Mg ha ${ }^{-1}$ year ${ }^{-1}$, and

$\mathrm{T}$ is the soil loss tolerance $\left(\mathrm{Mg} \mathrm{ha}^{-1} \mathrm{year}^{-1}\right)$.

\section{RESULTS AND DISCUSSION}

The erosivity values obtained for the SRW region (Figure 3a) showed that these range from $7,736.75$ to $8,080.75 \mathrm{MJ} \mathrm{mm} \mathrm{ha}^{-1} \mathrm{~h}^{-1}$ year ${ }^{-1}$, with an average of 7,859.77 MJ mm ha $\mathrm{Mm}^{-1} \mathrm{~h}^{-1}$ year ${ }^{-1}$. According to Carvalho (2008), erosivity values in the SRW are classified as strong. The values obtained corroborate with the analysis carried out by Steinmetz et al. (2018) for the Pelotas and Fragata rivers watersheds, located in the Pelotas region, with erosivity values between 7,640.64 and 8,750 MJ mm $\mathrm{ha}^{-1} \mathrm{~h}^{-1}$ year ${ }^{-1}$.

The values of factor $\mathrm{R}$ vary according to the DEM in the watershed; that is, the highest and lowest $R$ values occur in places of higher and lower altitudes, respectively.
Also noteworthy is the occurrence of higher $\mathrm{R}$ values in regions with Yellow Argisol (Figure 2a, Figure 3a).

The erodibility factor, through kriging, ranged from 0.03347 to 0.03512 (Figure 3b), with an average of $0.03464 \mathrm{Mg} \mathrm{h} \mathrm{MJ}^{-1} \mathrm{~mm}^{-1}$. In an experiment implemented by Denardin (1990), in Rio Grande do Sul, K values equal to $0.024,0.032$, and $0.034 \mathrm{Mg} \mathrm{h} \mathrm{MJ}^{-1} \mathrm{~mm}^{-1}$ were observed for argisols, with an average of $0.030 \mathrm{Mg} \mathrm{h} \mathrm{MJ}^{-1} \mathrm{~mm}^{-1}$. Therefore, the estimated values for the same soil classes did not present great differences between those estimated in the present study. The most substantial differences for the $\mathrm{K}$ factor are observed in Haplic Planosol, for which the tabulated value is equal to $0.0553 \mathrm{Mg} \mathrm{h} \mathrm{MJ} \mathrm{mm}^{-1}$, whereas the average kriging is $0.0336 \mathrm{Mg} \mathrm{h} \mathrm{MJ}^{-1} \mathrm{~mm}^{-1}$. Kriging is a method that tends to soften the minimum and maximum values. As the area represented by Planosol is $2.17 \%$, the interpolated values of $\mathrm{K}$ may have been affected by the smoothing effects imposed by the kriging method. The differences observed for the $\mathrm{K}$-factor also indicate pedogenic variations resulting from the different climates of the region. 


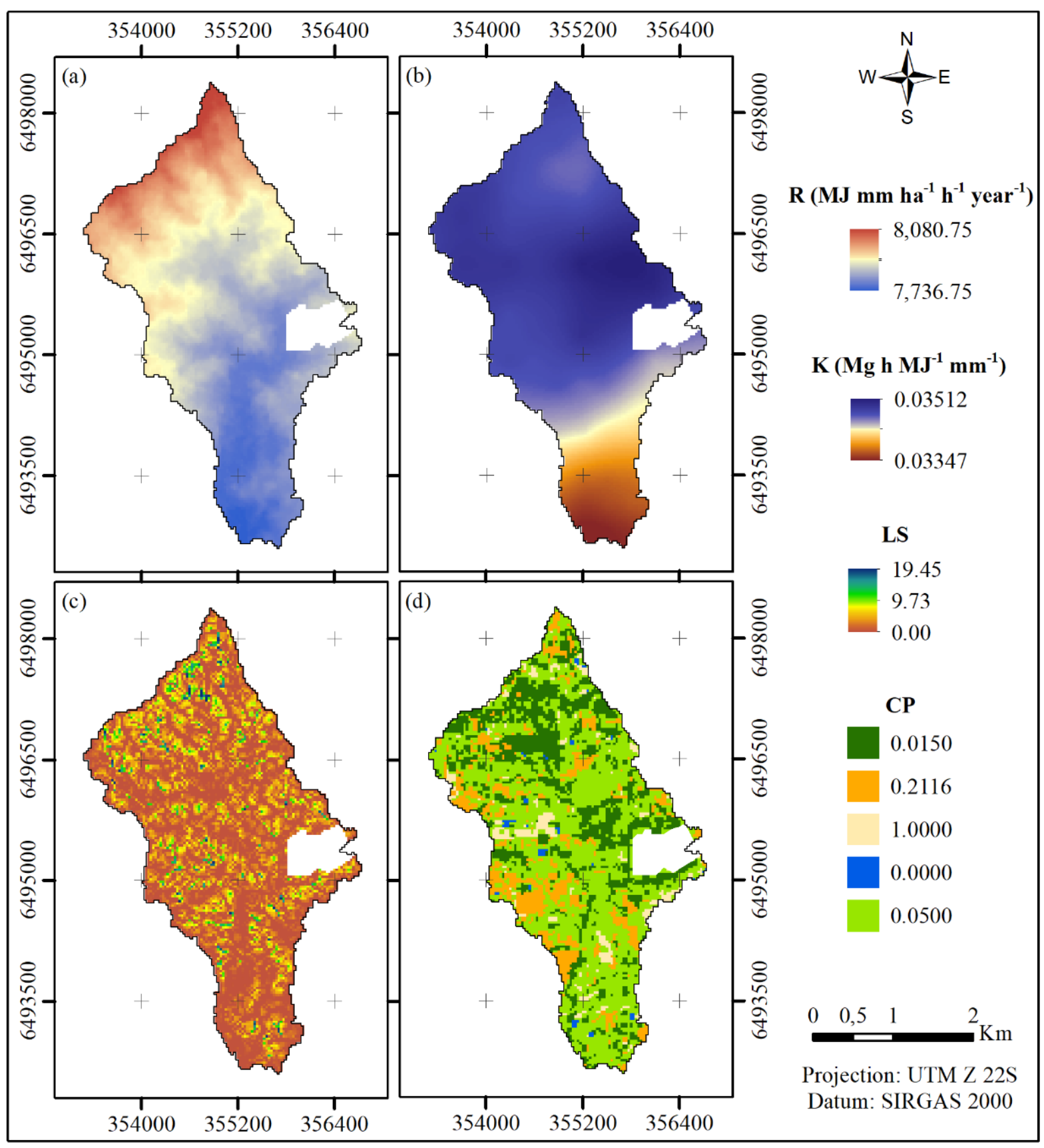

FIGURE 3. Rainfall erosivity (R), Soil erodibility (K), Topographic (LS), and Cover management and support practice (CP) factors for the Santa Rita Watershed (SRW), located in Southern Brazil.

The LS factor in the SRW ranges from 0 to 19.45 (Figure 3c), with an average of 1.35. According to Beskow et al. (2009), areas with LS < 10 can be considered to have low susceptibility to erosion. On analyzing the spatial distribution of the LS factor, areas with LS $<10$ represented $99.61 \%$ of the SRW, whereas higher values of the topographic factor were not very representative $(0.65 \%)$. Furthermore, the LS values obtained for the SRW were higher in places with a greater slope and lower in flatter areas. The results of this study corroborate those obtained by Steinmetz et al. (2018) for two watersheds in the same region ( $\mathrm{LS}=0-25)$.

From Figure 3d, it can be seen that the predominant land uses in SRW are grassland and native forest located predominantly in flatter areas. The uses corroborate those found by Valadão et al. (2018) in the Fragata River watershed. However, no sites with exposed soil were identified, possibly due to the different stages of annual cropping development during the period in which the classification of both works was carried out.

Soil losses in the SRW range from 0 to $3,281.57$ $\mathrm{Mg} \mathrm{ha}^{-1}$ year $^{-1}$ (Figure 4a), with an average annual loss of $35.94 \mathrm{Mg} \mathrm{ha}^{-1}$ year $^{-1}$. The greatest loss observed resulted from the combination of Yellow Argisol with exposed soil on strongly undulated slopes (Figure 5). In addition, it is possible to identify that both the higher portions of the watershed and the places with a predominance of exposed soil and annual cropping present the highest soil losses. 


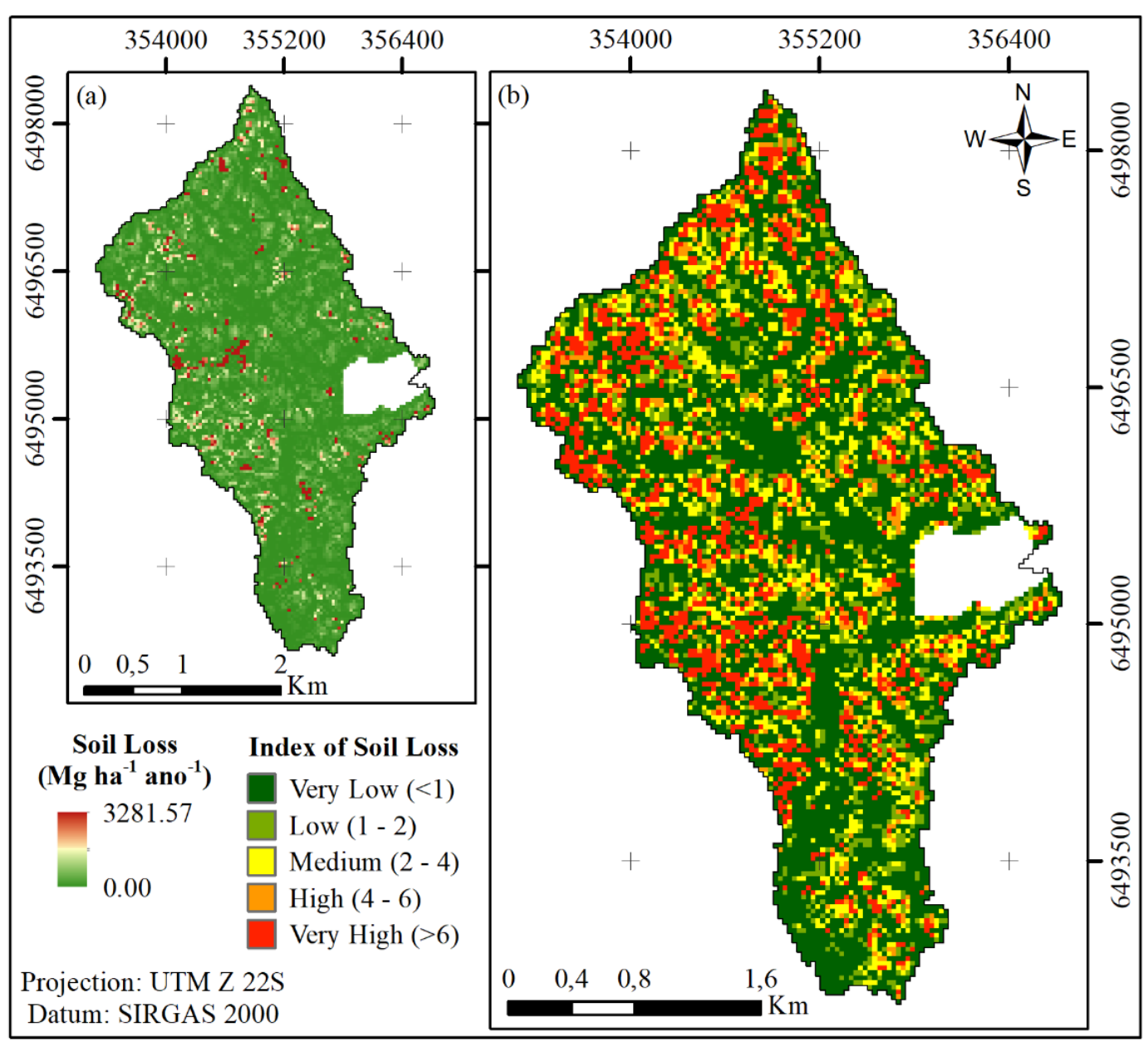

FIGURE 4. Soil Loss (a) and Index of Soil Loss (b) for the Santa Rita Watershed (SRW), located in Southern Brazil.
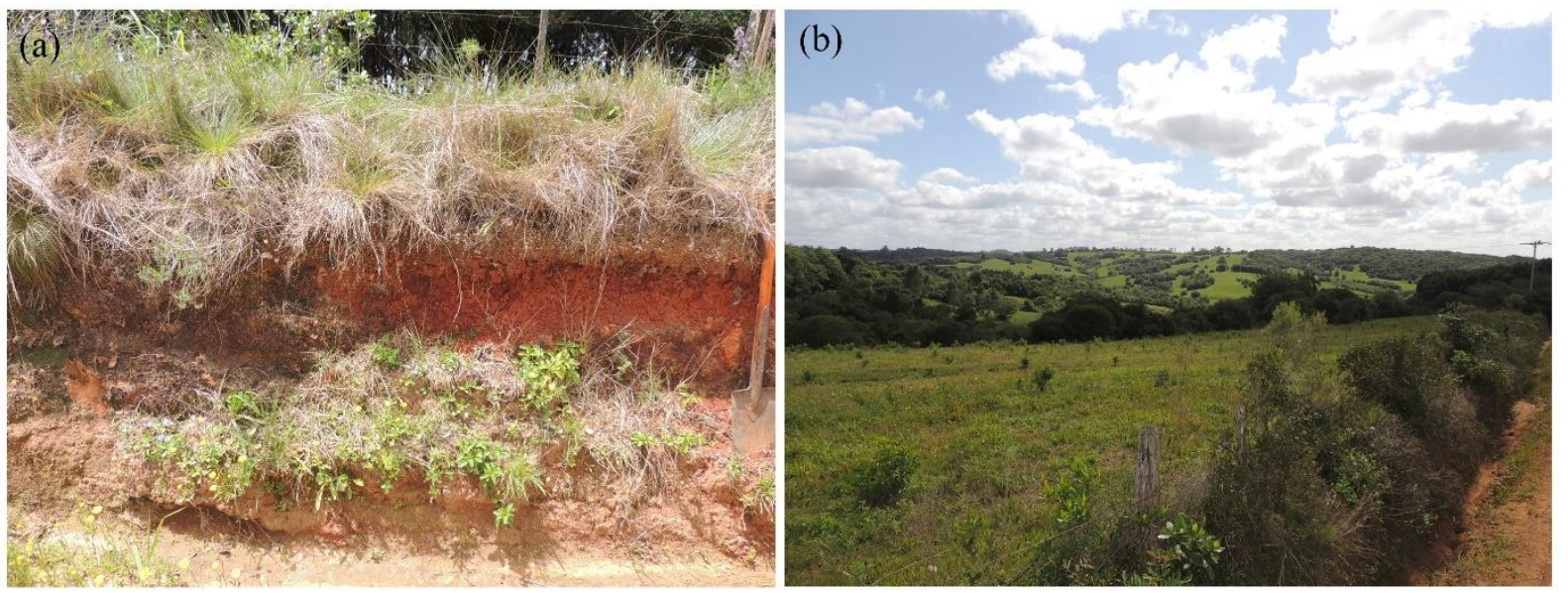

FIGURE 5. Yellow Argisol (a) and strong-undulated slopes (b) in the watershed Santa Rita (SRW).

Although SRW is a small watershed and has classes of land use that promote soil protection (grassland and native forest), it has critical areas susceptible to soil loss. This fact can be conditioned as much as the location of these areas in the landscape of the slope as to the intensity of the local rainfall. Thus, these findings are relevant to the planning and management of the watershed, subsequently enabling the adoption of techniques to control and prevent soil loss.
When only arbitrary classifications are considered for the soil loss process, there is a subjective understanding of the actual existence of areas with susceptibility to erosion in watersheds. Thus, the $\mathrm{I}_{\mathrm{SL}}$ (Table 3 ) considers the rate of losses that are above tolerance, without the need to adopt arbitrary classifications because they vary with local geomorphology (Ghafari et al., 2017). 
TABLE 3. Percentage of area associated with the classes established for the index of soil loss according to the class of soil, land use, and slope of the Santa Rita watershed (SRW), located in Southern Brazil.

\begin{tabular}{clccccc}
\hline & Index Soil Loss Class & Very Low & Low & Medium & High & Very High \\
\hline & Classes analyzed & \multicolumn{5}{c}{ Area of SRW (\%) } \\
\hline \multirow{3}{*}{ Soil Class } & Yellow Argisol & 11.22 & 2.97 & 3.79 & 1.89 & 5.65 \\
& Red-Yellow Argisol & 40.19 & 8.02 & 10.55 & 4.40 & 9.15 \\
& Haplic Planosol & 1.87 & 0.22 & 0.06 & 0.00 & 0.02 \\
\hline \multirow{5}{*}{ Land Use Class } & Native Forest & 17.38 & 5.08 & 2.96 & 0.44 & 0.23 \\
& Annual Cropping & 6.01 & 0.22 & 0.53 & 0.61 & 6.74 \\
& Exposed Soil & 2.31 & 0.00 & 0.01 & 0.05 & 2.39 \\
& Water Body & 0.77 & 0.00 & 0.00 & 0.00 & 0.00 \\
& Grassland & 26.81 & 5.91 & 10.91 & 5.18 & 5.46 \\
\hline \multirow{6}{*}{ Slope } & $0 \%-3 \%$ & 10.12 & 0.68 & 0.29 & 0.10 & 0.23 \\
& $3 \%-8 \%$ & 24.90 & 5.29 & 3.95 & 1.40 & 3.44 \\
& $8 \%-20 \%$ & 17.86 & 5.12 & 9.64 & 4.56 & 10.24 \\
& $20 \%-45 \%$ & 0.39 & 0.11 & 0.53 & 0.23 & 0.92 \\
\hline
\end{tabular}

A high incidence of very high values for the loss index $\left(\mathrm{I}_{\mathrm{SL}}>6\right)$ was observed in the Red-Yellow Argisol soil class (Table 3). These areas present the highest percentages of annual cropping and exposed soil as well as slopes of $8 \%-20 \%$, which favors susceptibility to soil loss in SRW. At the same time, Red-Yellow Argisol also has a high incidence of very low values for the loss index ( $\mathrm{I}_{\mathrm{SL}}<$ 1) concentrated in places with grassland and native forest. Low $\mathrm{I}_{\mathrm{SL}}$ values were observed in Planosols due to their location in the flatter portions of the slope and the good coverage and predominance of grassland (Figure 2). In addition, Haplic Planosol had the highest tolerance values (11.98) compared to Yellow Argisol (6.06) and RedYellow Argisol (9.10), which favored lower $\mathrm{I}_{\mathrm{SL}}$ values (Figure 4).

In the Rio Grande watershed (Minas Gerais), Batista et al. (2017) observed a higher incidence of extreme loss classification values for annual crops and areas of exposed soil. In the SRW, it was noticed that the very high values of losses $\left(\mathrm{I}_{\mathrm{SL}}>6\right)$ are concentrated in annual crops and grassland areas. According to Wang et al. (2017), some grasslands may present a certain degree of degradation, which reduces vegetative cover and, consequently, soil protection. However, it is perceived that the high $\mathrm{I}_{\mathrm{SL}}$ values observed in grassland areas are associated with higher values for other factors, mainly LS and $\mathrm{R}$, emphasizing the need to implement integrated crop and grassland areas.

In areas with a slope lower than $8 \%$, the lowest erosion rates predominate, whereas, in areas with more accentuated slopes, the highest percentages of medium to very high losses were found. The lower $\mathrm{I}_{\mathrm{SL}}$ results from low LS values with a high percentage of areas with native forest, which provides adequate soil coverage (Didoné et al., 2015).

Although some characteristics indicate soil loss (e.g., exposed soil, high slope), an analysis is necessary considering all factors for decision-making. The continuous estimation of the $\mathrm{K}$ factor is predominant, allowing the spatialization of information and, consequently, the susceptibility to soil loss. Furthermore, the approach taken indicates soil management and conservation practices in the watershed, enabling the identification of the places where these practices should be applied.

\section{CONCLUSIONS}

Through variations in the classification of land use and erosivity in the Santa Rita watershed (SRW), which is located in southern Brazil, changes in the final estimates of losses are evidenced by the RUSLE model. It is recommended that agro-environmental management and conservation programs be directed to the areas with the greatest losses, especially those that vary between exposed soil and cultivated area during the year.

\section{ACKNOWLEDGMENTS}

The authors wish to thank the Coordenação de Aperfeiçoamento de Pessoal de Nível Superior (CAPES) and Fundação de Amparo à Pesquisa do Estado do Rio Grande do Sul (FAPERGS) for the scholarships to the first, second and fourth authors.

\section{REFERENCES}

Alvares CA, Stape JL, Sentelhas PC, Gonçalves JLM, Sparovek G (2013) Koppen's climate classification map for Brazil. Meteorologische Zeitschrift 22(6):711-728. DOI: https://doi.org/10.1127/0941-2948/2013/0507

Anache JAA, Bacchi CGV, Panachuki E, Alves Sobrinho T (2015) Assessment of methods for predicting soil erodibility in Soil Loss Modeling. Geociências 34(1):32-40.

Arnold JG, Srinivasan R, Muttiah RS, Williams JR (1998) Large Area Hydrologic Modeling and Assessment Part I: Model Development. Journal of the American Water Resources Association 34(1):73-89. DOI: https://doi.org/10.1111/j.1752-1688.1998.tb05961.x 
Bakker MM, Govers G, Jones RA, Rounsevell MDA (2007) The Effect of Soil Erosion on Europe's Crop Yields. Ecosystems 10(7):1209-1219. DOI: https://doi.org/10.1007/s10021-007-9090-3

Batista PVG, Silva MLN, Silva BPC, Curi N, Bueno IT, Acérbi Júnior FW, Davies J, Quinton J (2017) Modelling spatially distributed soil losses and sediment yield in the upper Grande River Basin - Brazil. Catena 157:139-150. DOI: https://doi.org/10.1016/j.catena.2017.05.025

Benavidez R, Jackson B, Maxwell D, Norton K (2018) A review of the (Revised) Universal Soil Loss Equation ((R)USLE): with a view to increasing its global applicability and improving soil loss estimates. Hydrology and Earth System Sciences 22:6059-6086. DOI: https://doi.org/10.5194/hess-22-6059-2018

Beskow S, Mello CR, Norton LD, Curi N, Viola MR, Avanzi JC (2009) Soil erosion prediction in the Grande River Basin, Brazil using distributed modeling. Catena 79(1):49-59. DOI:

https://doi.org/10.1016/j.catena.2009.05.010

Beskow S, Timm LC, Tavares VEQ, Caldeira TL, Aquino LS (2016) Potential of the LASH model for water resources management in data-scarce basins: a case study of the Fragata River basin, southern Brazil. Hydrological Sciences Journal 61(14):2567-2578. DOI: https://doi.org/10.1080/02626667.2015.1133912

Carvalho NO (2008) Hidrossedimentologia Prática. Rio de Janeiro, Editora Interciência, 599p.

Cunha NG, Silveira RJC, Severo CRC (2006) Solos e terras do planalto Sul-Rio-Grandense e planícies costeiras. Pelotas, Embrapa Clima Temperado, 42p.

Denardin JE (1990) Erodibilidade do solo estimada por meio de parâmetros físicos e químicos. Tese, Universidade de São Paulo, Piracicaba.

Derpsch R, Franzluebbers AJ, Duiker SW, Reicosky DC, Koeller K, Friedrich T, Sturny WG, Sá JCM, Weiss K (2014) Why do we need to standardize no-tillage research? Soil \& Tillage Research 137:16-22. DOI: https://doi.org/10.1016/j.still.2013.10.002

Didoné EJ, Minella JPG, Merten GH (2015) Quantifying soil erosion and sediment yield in a catchment in southern Brazil and implications for land conservation. Journal of Soils and Sediments 15:2334-2346. DOI: https://doi.org/10.1007/s11368-015-1160-0

EMBRAPA - Empresa Brasileira de Pesquisa Agropecuária (1979) Serviço Nacional de Levantamento e Conservação de Solos. Súmula da 10. Reunião Técnica de Levantamento de Solos. Rio de Janeiro.

ESRI - Environmental Systems Research Institute (2014) ArcGIS DESKTOP 10.1. CD-ROM.

Flanagan DC, Nearing MA (1995) Water erosion prediction project hillslope profile and watershed model documentation. West Lafayette, United States Department of Agriculture. Report 10.
Ghafari H, Gorji M, Arabkhedri M, Roshani GA, Heidari A, Akhavan S (2017) Identification and prioritization of critical erosion areas based on onsite and offsite effects. Catena 156:1-9. DOI: https://doi.org/10.1016/j.catena.2017.03.014

Gianinetto M, Aiello M, Polinelli F, Frassy F, Rulli MC, Ravazzani G, Bocchiola D, Chiarelli DD, Soncini A, Vezzoli R (2019) D-RUSLE: a dynamic model to estimate potential soil erosion with satellite time series in the Italian Alps. European Journal of Remote Sensing 52(4):34-53. DOI: http://dx.doi.org/10.1080/22797254.2019.1669491

Gomes L, Simões SJC, Dalla Nora EL, Sousa-Neto ER, Forti MC, Ometto JPHB (2019) Agricultural Expansion in the Brazilian Cerrado: Increased Soil and Nutrient Losses and Decreased Agricultural Productivity. Land 8(12):1-26. DOI: http://dx.doi.org/10.3390/land8010012

Hiemstra PH, Pebesma EJ, Twenhöfel CJW, Heuvelink GBM (2009) Real-time automatic interpolation of ambient gamma dose rates from the Dutch radioactivity monitoring network. Computers \& Geosciences 35(8):1711-1721. DOI: https://doi.org/10.1016/j.cageo.2008.10.011

Kavian A, Sabet SH, Solaimani K, Jafari B (2017) Simulating the effects of land use changes on soil erosion using RUSLE model. Geocarto International 32(1):97-111. DOI: https://doi.org/10.1080/10106049.2015.1130083

Khan AM, Qureshi R, Saqib Z (2019) Multivariate analyses of the vegetation of the western Himalayan forests of Muzaffarabad district, Azad Jammu and Kashmir, Pakistan. Ecological Indicators 104:723-736. DOI: https://doi.org/10.1016/j.ecolind.2019.05.048

Lense GHE, Moreira RS, Parreiras TC, Santana DB, Bolelli TM, Mincato RL (2020) Water erosion modeling by the Erosion Potential Method and the Revised Universal Soil Loss Equation: a comparative analysis. Revista Ambiente \& Água 15(4). DOI: http://dx.doi.org/10.4136/ambi-agua.2501

Lupatini M, Jacques RJS, Antoniolli ZI, Suleiman AKA, Fulthorpe RR, Roesch LFW (2013) Land-use change and soil type are drivers of fungal and archaeal communities in the Pampa biome. World Journal of Microbiology Biotechnology 29:223-33. DOI: https://doi.org/10.1007/s11274-012-1174-3

Mannigel AR, Carvalho MP, Moreti D, Medeiros LR (2002) Fator erodibilidade e tolerância de perda dos solos do Estado de São Paulo. Acta Scientiarum 24(5):1335-1340. DOI: https://doi.org/10.4025/actasciagron.v24i0.2374

Markose VJ, Jayappa KS (2016) Soil loss estimation and prioritization of sub-watersheds of Kali River basin, Karnataka, India, using RUSLE and GIS. Environmental Monitoring and Assessment 188:225. DOI: https://doi.org/10.1007/s10661-016-5218-2

Martín Duque JF, Zapico I, Oyarzun R, López García JA, Cubas P (2015) A descriptive and quantitative approach regarding erosion and development of landforms on abandoned mine tailings: New insights and environmental implications from SE Spain. Geomorphology 239:1-16. DOI: https://doi.org/10.1016/j.geomorph.2015.02.035 
Mello CR, Viola MR, Beskow S, Norton LD (2013)

Multivariate models for annual rainfall erosivity in Brazil. Geoderma 202-203:88-102. DOI:

https://doi.org/10.1016/j.geoderma.2013.03.009

Merritt WS, Letcher RA, Jakeman AJ (2003) A review of erosion and sediment transport models. Environmental Modelling \& Software 18(8-9):761-799. DOI: https://doi.org/10.1016/S1364-8152(03)00078-1

Miguel P (2010) Land Use and Soil Loss in Hillslope Areas - Evaluation of the Vacacaí-Mirim River Catchment, Santa Maria, RS. Dissertation of Master's degree, Federal University of Santa Maria.

Minella JPG, Merten GH, Ruhoff AL (2010) Use of spatial representation to calculate the topographic factor in the Revised Universal Soil Loss Equation in watersheds. Revista Brasileira de Ciência do Solo 34(4):1455-1462. DOI: https://doi.org/10.1590/S0100-06832010000400041

Moore ID, Burch GJ (1986) Physical Basis of the Lengthslope Factor in the Universal Soil Loss Equation. Soil Science Society of America Journal 50(5):1294-1298. DOI: https://doi.org/10.2136/sssaj1986.03615995005000050042x

Napoli M, Cecchi S, Orlandini S, Mugnai G, Zanchi CA (2016) Simulation of field-measured soil loss in Mediterranean hilly areas (Chianti, Italy) with RUSLE. Catena 145:246-256. DOI:

https://doi.org/10.1016/j.catena.2016.06.018

Panditharathne DLD, Abeysingha NS, Nirmanee KGS, Mallawatantri A (2019) Application of Revised Universal Soil Loss Equation (Rusle) Model to Assess Soil Erosion in "Kalu Ganga" River Basin in Sri Lanka. Applied and Environmental Soil Science 2019:1-15. DOI: https://doi.org/10.1155/2019/4037379

Reicosky DC (2015) Conservation tillage is not conservation agriculture. Journal of Soil and Water Conservation 70(5):103-108A. DOI:

https://doi.org/10.2489/jswc.70.5.103A

Renard KG, Foster GR, Weisies GA, McCool DK, Yoder DC (1997) Predicting Soil Erosion by Water: A Guide to Conservation Planning With the Revised Universal Soil Loss Equation (RUSLE). Washington, United States Department of Agriculture, Report No. 703.

Rocha J, Rocha N, Käfer P, Cruz R (2020) Eucalyptus forestry in Brazilian Pampa biome: between developmental illusion and sustainable inefficacy. Ciência e Natura 42:e35. DOI:

https://doi.org/10.5902/2179460X40990

Santos GB, Valentini MHK, Silva LA, Franz HS, Corrêa BL, Viana FV, Corrêa MG, Vieira BM, Nadaleti WC, Leandro D, Vieira BM (2020) Avaliação dos parâmetros e do índice de qualidade da água para o Arroio

Moreira/Fragata, Pelotas/RS. Revista Ibero-Americana de Ciências Ambientais 11(4):287-299. DOI:

http://doi.org/10.6008/CBPC2179-6858.2020.004.0024

Sharpley AN, Villiams JR (1990) EPIC-

Erosion/Productivity Impact Calculator: 1. Model

Documentation. Baltimore, United States Department of Agriculture. Technical Bulletin 1768.
Silva TS (2016) Soil erodibility of an Ultisol and management and cover factor of the Universal Soil Loss Equation. Dissertation of Master's degree, Federal University of Rio Grande do Sul.

Silva LCN, Luchiari A (2016) Estimating Soil Loss by Sheet Erosion in the Basin of Córrego Baguaçu-SP. Revista do Departamento de Geografia 32:15-28. DOI: https://doi.org/10.11606/rdg.v32i0.114308

Silva FGB, Minotti RT, Lombardi Neto F, Primavesi O, Crestana S (2010) Loss of soil determination in Fazenda Canchim - SP (EMBRAPA) using geographic information systems and USLE 2D. Engenharia Sanitária e Ambiental 15(2):141-148. DOI: https://doi.org/10.1590/S141341522010000200006

Silva BPC, Silva MLN, Batista PVG, Pontes LM, Araújo $\mathrm{EF}$, Curi N (2016) Soil and water losses in eucalyptus plantation and natural forest and determination of the USLE factors at a pilot sub-basin in Rio Grande do Sul, Brazil. Ciência e Agrotecnologia 40(4):432-442. DOI: https://doi.org/10.1590/1413-70542016404013216

Smith RM, Stamey WL (1964) How to establish erosion tolerances? Journal of Soil and Water Conservation 19(3):110-111.

Steinmetz AA, Cassalho F, Caldeira TL, Oliveira VA, Beskow S, Timm LC (2018) Assessment of soil loss vulnerability in data-scarce watersheds in southern Brazil. Ciência e Agrotecnologia 42(6):575-587. DOI: https://doi.org/10.1590/1413-70542018426022818

Sudhishri S, Kumar A, Singh JK, Dass A, Nain AS (2014) Erosion tolerance index under different land use units for sustainable resource conservation in a Himalayan watershed using remote sensing and geographic information system (GIS). African Journal of Agricultural Research 9(41):3098-3110. DOI: https://doi.org/10.5897/AJAR2013.7933

Valadão LS, Pereira RS, Silva MD, Monks JLF (2018) Spatial characterization and analysis of water quality in the basin of the Stream Moreira/Fragata, RS. Revista Thema 15(1):282-297. DOI:

http://dx.doi.org/10.15536/thema.15.2018.282-297.554

Wang Z, Deng X, Song W, Li Z, Chen J (2017) What is the main cause of grassland degradation? A case study of grassland ecosystem service in the middle-south Inner Mongolia. Catena 150:100-107. DOI: https://doi.org/10.1016/j.catena.2016.11.014

Wischmeier WH, Smith DD (1978) Predicting rainfall erosion losses - a guide to conservation planning. Washington, United States Department of Agriculture, Agriculture Handbook No. 537.

Wreford A, Ignaciuk A, Gruère G (2017) Overcoming barriers to the adoption of climate-friendly practices in agriculture. Papers 101. Paris, OECD Publishing. DOI: http://dx.doi.org/10.1787/97767de8-en. 